This journal is the official publication of Bangladesh Society of Physiologists (BSP)

Web URL: www.banglajol.info/index.php/JBSP

Abstracted /indexed in Index Copernicus, Director of Open Access Journal, HINARI Index Medicus for South East Asia Region, Google Scholar, 12OR, infobse index, Open J gate, Cite factor, Scientific indexing services

pISSN-1983-1213; e-ISSN-2219-7508

\title{
Article
}

Article information:
Received: 24th September 2019
Accepted: 23rd March 2020
DOI: https://doi.org/10.3329/jbsp.v15i1.48110

Corresponding author:

Farhana Fatema, Department of Physiology, MARKS Medical College, Dhaka. Phone: 01670827434,E-mail: dr.ffheya@gmail.com

Cite this article:

Fatema F, Nahar S, Akhter QS. Cyclophosphamide induced anemia in Wistar rats: can it be prevented by Sajna (Moringaoleifera)? J Bangladesh Soc Physiol 2020;15(1): 11-16

This article is open access licensed under CC BY NC SA which allows readers copy, distribute, display, and perform the work and make derivative works based on it only for noncommercial purposes.

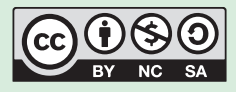

Volume 15 No. 1 June 2020: 11-16

\section{Cyclophosphamide induced anemia in Wistar rats: can it be prevented by Sajna (Moringaoleifera)?}

Farhana Fatema ${ }^{1}$, Sharmin Nahar ${ }^{1}$, Qazi Shamima Akhter ${ }^{1}$

1. Department of Physiology, Dhaka Medical College, Dhaka.

\section{Abstract}

Background:Chemotherapy-induced anemia is a multifactorial challenge to the treatment of malignancy. Herbal medicine may help totreat such anemia due to its natural compatibility. Moringaoleifera (Sajna), is well known for preventing and curing anemia. Objective: To evaluate the preventive effect of aqueous extract of Moringaoleiferaleaf (AEMOL) on cyclophosphamide (CP) induced anemia in Wistar rats. Method: The experimental study was carried out in the Department of Physiology, Dhaka Medical College, Dhaka from July 2015 to June 2016. Thirty Wistar ratsof both sexes weighing $175 \pm 25 \mathrm{gm}$ were grouped as A[normal saline $(1 \mathrm{ml} / \mathrm{kg})$; oral], and B [CP (3mg/kg);i. p.], C[AEMOL (300mg/kg); oral], D [AEMOL(300mg/kg); oral and $\mathrm{CP}(3 \mathrm{mg} / \mathrm{kg})$ i. p. simultaneously for 14 consecutive days] and $\mathrm{E}$ [AEMOL $(300 \mathrm{mg} / \mathrm{kg})$; oralfor 14 consecutive days and CP $(30 \mathrm{mg} /$ $\mathrm{kg})$; i. p. on $12^{\text {th }}, 13^{\text {th }}, 14^{\text {th }}$ day] with 6 rats in each group. All the rats had free access to food and distilled water during the period of acclimatization (seven days) and experiment(fourteen days). Total count(TC)) of RBC, hemoglobin ( $\mathrm{Hb}$ ) level and packed cell volume (PCV)were estimated to assess anemia in all rats before and after experiment. The statistical analyses were done by one way ANOVA followed by Bonferroni post hoc test where $\mathrm{p}<0.05$ was accepted as level of significance.Result: The mean TCof $\mathrm{RBC}, \mathrm{Hb} \%$ and $\mathrm{PCV}$ were significantly $(\mathrm{p}<0.001)$ lower in $\mathrm{CP}$ treated rats (group B), in comparison to all other rats of different groups (A, C, D and E). In addition, all these three variables were significantly higher in AEMOLtreated group $(C)$ compared to saline treated rats (A)but almost similar in rats with two groups of different dose schedule of AEMOL and CP (D, E).Conclusion:From the study, it can be concluded that $\mathrm{CP}$ induced anemia can be prevented by AEMOL used either simultaneously or in an anticipating manner.

Keyword: Moringaoleifera, Cyclophosphamide, anemia, Hb, PCV. 
Introduction

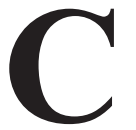

yclophosphamide, is a synthetic antineoplastic drug, currently used for treatment of tumors, lymphomas, leukemias and as an immuno-suppressive agent before bone marrow and organ transplantation. ${ }^{1}$ In addition to its common adverse effects nausea, vomiting, alopecia, mucosal ulceration, blood cell counts, as well as hemoglobin percentagehas also been reporteddue to bone marrow suppression ${ }^{3}$. So, anemia is one of the common and recurrent consequence of patients receiving drugs like $\mathrm{CP}{ }^{4}$

To overcome this unwanted side effect (anemia), synthetic hematinicsare used therapeutically, but they are costly, not user friendly and some of them have potential side effects of their own.On the contrary, medicinal herbs are cheap, easily available and usually free from any detrimental effects as well as better compatibility. ${ }^{5}$

Different medicinal plants like Astragaliradix, Angelicae Radix, ${ }^{6}$ Vernonia amygdalina ${ }^{7}$, Jatropha curcas $^{8}$, Zanthoxylumzanthoxyloide ${ }^{9}$, Jatropha tanjorensis,Betavulgaris,Solanum melongena $^{10}$, Acalypha wilkesiana ${ }^{11}$, Amaranthus cruentu ${ }^{4}$, are studied widely against CP induced anemia in various animal models.

But recently, 'Sajna', [Moringaoleifera (Family: Moringaceae)], 'the miracle tree', isa medicinal plant,also has shown to possess hypocholesterolemic, hepatoprotective, anticancer, analgesic, anticovulsant, antibiotic, anti-allergic and anti-inflammatory, antidiabetic, antioxidanteffects. ${ }^{12-20}$

In addition to these studies, 14 days oral supplementation of Moringaoleiferaleaf(MOL) extract, was found to increase RBC count in healthy adults. ${ }^{21}$ Moreover, it also improved hemoglobin level of iron deficient women after 30 days of MOL supplementation. ${ }^{22}$ Furthermore, this medicinal plant extract was shown to increase $\mathrm{RBC}$ count and hemoglobin concentration after different dose schedules in sodium arsenite ${ }^{23}$ as well as aluminium induced anemia ${ }^{24}$ in two nephrotoxicity and hepatic toxicity, ${ }^{2}$ lowering of

different rat models. Moreover, $\mathrm{RBC}$ count, $\mathrm{Hb}$ concentration and PCV were found significantly higher in rats with 14 days MOL treatment in comparison to those of without treatment rats. ${ }^{25}$

However, as far as it has been searched, no reported data regarding cyclophosphamide induced anemia prevention by MOL was available. On the basis of this background, this study was designed to evaluate the preventive role of aqueous extract of Moringaoleifera leaf(MOL) on cyclophosphamide induced anemia in Wistar rats.

\section{Method}

The prospective experimental study was carried out in the Department of Physiology, Dhaka Medical College and Hospital (DMCH), Dhaka from July 2015 to June 2016. Animal care and experiments were performed according to guidelines set in the 'The ethical guidelines for experimentation in laboratory animals' by the Animal Experimentation Ethics Committee (AEEC) of the International Centre for Diarrhoeal Disease Research, Bangladesh ${ }^{26}$ ( icddr,b 2002) and the ethical clearance was taken from Ethical Review Committee of Dhaka Medical College.

Procurement and maintenance of animals:

A total number of 30 rats of both sexes, weighing $175 \pm 25$ gm were collected from the animal house of Department of Pharmacy, Jahangirnagar University, Savar, Dhaka. The animals were housed in metallic cases in the animal house of Institute of Nutrition and Food Science, University of Dhaka, under a 12/12 hour light/ dark cycle ${ }^{27}$. The ambient room temperature was maintained at around 27 to $28^{\circ} \mathrm{C}$, corresponding to the thermo neutral zone for rodents ${ }^{28}$. They had free access to food and water ad libitum. The rats were kept for seven consecutive days for environmental acclimatization prior to the experiment.

\section{Grouping and dose schedule:}

After acclimatization for 7 days, the rats were divided into five groups (A, B, C, D and E) of six rats in each group. In addition to basal diet, they were treated as follows:
Volume 15 No. 1 June 2020: 11-16 
Table I: Grouping and dose schedule for Wistar rats $(\mathrm{N}=30)$

\begin{tabular}{|c|c|c|c|c|c|}
\hline Groupsrats/group) & Treatment & Route & \multicolumn{2}{|c|}{ Dose(per kg body weight) } & Duration \\
\hline$A(n=6)$ & normal saline & oral & $1 \mathrm{ml}$ & 14 consecutiv & days \\
\hline $\mathrm{B}(\mathrm{n}=6)$ & $\mathrm{CP}$ & i.p. & $3 \mathrm{mg}$ & 14 consecutiv & days \\
\hline$C(n=6)$ & AEMOL & oral & $300 \mathrm{mg}$ & 14 consecutiv & days \\
\hline $\mathrm{D}(\mathrm{n}=6)$ & AEMOL and $\mathrm{CP}$ & $\begin{array}{l}\text { AEMOL(oral); } \\
\text { CP (i.p.) }\end{array}$ & $\begin{array}{l}\text { AEMOL300mg; } \\
\text { CP3 mg. }\end{array}$ & $\begin{array}{l}14 \text { consecutiv } \\
\text { simultaneousl }\end{array}$ & days \\
\hline$E(n=6)$ & $\mathrm{AEMOL}$ and $\mathrm{CP}$ & $\begin{array}{l}\text { AEMOL(oral); } \\
\text { CP (i.p.) }\end{array}$ & $\begin{array}{l}\text { AEMOL300mg; } \\
\text { CP30 mg. }\end{array}$ & $\begin{array}{l}\text { AEMOL for } 1 \\
\text { consecutive } d_{\text {d }} \\
12^{\text {th }}, 13^{\text {th }}, 14^{\text {th }}\end{array}$ & $\begin{array}{l}\text { ys; CP on } \\
\text { day }\end{array}$ \\
\hline
\end{tabular}

$\mathrm{CP}=$ cyclophosphamide; $\mathrm{AEMOL}=$ aqueous extractofMoringaoleifera leaf; i.p. $=$ intraperitoneal, $\mathrm{N}=$ total number of rats; $n=$ number of rats in each group.

Table II: Study variables in different groups of rats and their statistical analysis ( $\mathrm{N}=30)$

\begin{tabular}{|c|c|c|c|c|}
\hline \multirow[b]{2}{*}{ Parameters } & \multicolumn{4}{|c|}{ Groups } \\
\hline & $\begin{array}{c}A \\
(n=6)\end{array}$ & $\begin{array}{c}B \\
(n=6)\end{array}$ & $\begin{array}{c}C \\
(n=6)\end{array}$ & $\begin{array}{c}D \\
(n=6)\end{array}$ \\
\hline$\overline{R B C}$ count $\left(\right.$ x $\left.10^{6} / \mu \mathrm{l}\right)$ & $7.89 \pm 0.47$ & $3.86 \pm 0.64$ & $8.12 \pm 0.58$ & $7.41 \pm 0.45 \quad 7.08 \pm 0.51$ \\
\hline Hemoglobin(gm/dl) & $12.10 \pm 0.83$ & $8.10 \pm 0.67$ & $14.19 \pm 1.02$ & $13.86 \pm 0.8412 .94 \pm 0.91$ \\
\hline $\operatorname{PCV}(\%)$ & $43.98 \pm 2.25$ & $19.06 \pm 1.24$ & $41.14 \pm 1.43$ & $40.53 \pm 1.1838 .78 \pm 1.05$ \\
\hline \multirow[t]{2}{*}{ Groups } & & P value & & \\
\hline & $\mathrm{RBC}$ & Hemoglobin & $\mathrm{PCV}$ & \\
\hline$A$ vs $B$ vs $C$ vs $D$ vs $E$ & $<0.001^{* * *}$ & $<0.001^{* * *}$ & $<0.001^{* * *}$ & \\
\hline A vs B & $<0.001^{* * *}$ & $<0.001^{* * * *}$ & $<0.001^{* * *}$ & \\
\hline A vs $C$ & $0.049^{*}$ & $0.003^{* *}$ & $0.030^{*}$ & \\
\hline A vs D & $1.000^{\mathrm{ns}}$ & $0.016^{*}$ & $0.005^{* *}$ & \\
\hline A vs E & $0.091 \mathrm{~ns}$ & $1.000^{\mathrm{ns}}$ & $<0.001^{* * *}$ & \\
\hline $\mathrm{B}$ vs $\mathrm{C}$ & $<0.001^{* * *}$ & $<0.001^{* * *}$ & $<0.001^{* * *}$ & \\
\hline B vs D & $<0.001^{* * *}$ & $<0.001^{* * *}$ & $<0.001^{* * *}$ & \\
\hline B vs E & $<0.001^{* * *}$ & $<0.001^{* * *}$ & $<0.001^{* * *}$ & \\
\hline C vs D & $0.001^{* *}$ & $1.000^{\mathrm{ns}}$ & $1.000^{\mathrm{ns}}$ & \\
\hline C vs E & $<0.001^{* * *}$ & $0.188^{\mathrm{ns}}$ & $0.110^{\mathrm{ns}}$ & \\
\hline D vs E & $1.000^{\mathrm{ns}}$ & $0.774^{\mathrm{ns}}$ & $0.520^{\mathrm{ns}}$ & \\
\hline
\end{tabular}

Results are expressed as mean \pm SEM; The statistical analysis was done by one way ANOVA followed by Bonferroni post hoc test. $\mathrm{N}=$ Total number of rats, $\mathrm{n}=$ number of rats in each group;ns = not significant; $* / * * /$ *** = significant;A:[normal saline ( $1 \mathrm{ml} / \mathrm{kg})$; oral]; B [CP $(3 \mathrm{mg} / \mathrm{kg}) ; \mathrm{i} . \mathrm{p}$.]; C[aqueous extract ofMoringaoleifera leaf $(300 \mathrm{mg} / \mathrm{kg})$;oral]; D [aqueous extract ofMoringaoleifera leaf $(300 \mathrm{mg} / \mathrm{kg})$; oral and $\mathrm{CP}(3 \mathrm{mg} / \mathrm{kg})$ i.p. simultaneously for 14 consecutive days]; E [AEMOL(300mg/kg); oralfor 14 consecutive days and CP(30mg/ $\mathrm{kg})$; i. p. on $12^{\text {th }}, 13^{\text {th }} \& 14^{\text {th }}$ day.] 


\section{Blood collection:}

On $15^{\text {th }}$ day of experiment, rats were deeply anaesthetized by $30 \%$ chloroform. Two (2) $\mathrm{ml}$ blood samples were drawn through cardiac punctureand collected in EDTA tubesto be analyzed by Automated Hematology Analyzer XT-SYSMEX-2000i; in the Department of Hematology, DMCH.

\section{Euthanasia:}

Painless deaths of the deeply anesthetized rats were ensured by decapitation. ${ }^{29}$

\section{Statistical analysis:}

Resultswere expressed as mean \pm SEM. Statistical analysis were done by one way ANOVA followed by Bonferroni post hoc test. In the interpretation of results, $p$ value $<0.05$ was accepted as level of significance.

\section{Results}

As shown in Table II, the total count of RBC, hemoglobin percentage and PCV were significantly $(\mathrm{p}<0.001)$ lower in group $B(C P$ treated), in comparison to group A (normal saline treated).Again, these parameters were significantly $(\mathrm{p}<0.001)$ higher in group D (AEMOL and CP simultaneously treated) and $\mathrm{E}$ (AEMOL and $\mathrm{CP}$ simultaneously treated) in comparison to $\mathrm{CP}$ treated (B) group.Besides, all these three parameters were almost similar in group D (AEMOL and CP simultaneously treated) and $\mathrm{E}$ (AEMOL pretreated and CP post treated). However, these parameters were significantly higher in group $\mathrm{C}$, in comparison to those of group A $(p<0.05), B(p<0.01)$.

\section{Discussion}

In this study, mean total count of RBC, hemoglobin level, PCV were estimated to assess hematological changes. Here, all these three parameters were significantly lower in $\mathrm{CP}$ treated rats in comparison to those of normal.This finding is similar to different studies. $5,3,30$ Cyclopho-sphamide induced production of free radicals might be causing lipid peroxidation and subsequent cell damage ${ }^{1}$ resulting anemia in our rats.

In addition, AEMOL prevented the $\mathrm{CP}$ induced anemia in our experimental rats. It has been suggested that MOL possesses antioxidants (polyphenols, flavonoids, vitamin A,C,E) 31 exhibiting strong scavenging effect on different free radicals (superoxide, nitric oxide radical) inhibiting lipid peroxidation and preventing oxidative damage to major biomolecules. ${ }^{32}$

Moreover, MOL also possess different hemopoietic factors, such as vitamins $\left(A, B_{1}, B_{2}\right.$, $\mathrm{B}_{12} \mathrm{C}, \mathrm{E}, \mathrm{K}$, folic acid), minerals ( $\mathrm{Mg}, \mathrm{P}, \mathrm{Na}, \mathrm{K}$, $\mathrm{Ca}, \mathrm{Fe}, \mathrm{Mn}, \mathrm{Zn}, \mathrm{Cu}, \mathrm{Se}$ ), essential amino acids ${ }^{33}$ (Okot-Asi et al. 2015) which might cause growth, differentiation, proliferation of hemopoietic stem cell as well as maturation of DNA and $\mathrm{RBC}^{34}$. This hematinic potential of MOL might cause the prevention of CP induced anemia in our rats.

Moreover, in the present study, CP induced anemia was prevented by AEMOL, used either simultaneously with CP (group D) or in an anticipating manner (group E). Though induction of anemia by CP was with different dose schedule, but correction by AEMOL was almost similar in both groups D and E.However, the exact mechanism cannot be elucidated as free radical concentration produced by $\mathrm{CP}$ and phytochemical contents of Moringaoleifera leaf were not assessed in the present study.

\section{Conclusion}

The present study reveals that AEMOL has preventive role against cyclophosphamide induced anemia. So, it can be concluded that Moringaoleifera leaf has the potential to prevent anemia either in sudden or simultaneous exposure to bone marrow suppressing agent like CP.

Conflict of interest - None.

Acknowledgement

The authors acknowledge Professor Sheikh Nazrul Islam, Institute of Nutrition and Food

Volume 15 No. 1 June 2020: 11-16 
Science, University of Dhaka, for his kind cooperation regarding animal housing, plant extract preparation and dose calculation.

\section{References}

1. Haubitz M. Acute and Long-term Toxicity of Cyclophosphamide. Transplantationsmedizin 2007; 19: 26-31.

2. Mahmoud AM, Hussein OE, Ramadan SA. Amelioration of cyclophosphamide-induced hepatotoxicity by the brown Seaweed Turbenariaornata. Int J ClinToxicol 2013; 1(1):9-17.

3. Sheetla C, Nargis K, Rajendra C, Arun RK, Vinoy SK. Cyclophosphamide induced changes in hematological and biochemical parameters of adult male RattusNorvegicus. Int J ApplBiol Pharm Technol 2013; 4(2):74-8.

4. Pandey S, Ganeshpurkar A, Dubey A. Hematopoietic effect of Amaranthuscruentus extract on cyclophosphamide induced toxicity in rats. PhamacognCommn 2019;9(4): 139-142.

5. Okwuosa CN, Achukwu PUO, Azubike NC, Abah AIE. Protective effect of the leaf extracts of Combretumracemosum P. Beauv(Combretaceae)on cyclophosphamide induced pancytopaniaand liver injury in male rats. Res J Pharmacol 2012; 6(12):3034.

6. Chang MS, Kim DR, Ko EB, Choi BJ, Park SY, Park SK. Treatment with Astragali radix and Angelicae Radix enhances erythropoietin gene expression in the CP induced anemia in rats.J Med Food 2009;3(12):637-642.

7. Ikeh, Kenedy C, Erebi P, Ezike, Adaobi C. Protective potential of aqueous leaf extract of Vernoniaamygdalinain cyclophosphamide induced myelotoxicity. J Pharm.2014; 4(3): 06-14.

8. Chukwuemeka I, Uttuk GK, Ugwu PC, Okechwkwu.The effect of ethanol extract of Jatrophacurcas on some hematological parameters of $\mathrm{CP}$ induced anemia in Wistar rats. Eur J Appl Sci.2015;7(1): 17-20.

9. Ikumawoyi VO, Awodele O, Rotimi K, FashinaAY.Evaluation of the effects of the hydroalcoholic extract of Zanthoxyloides on hematological parameters and oxidative stress in cyclophosphamide treated rats.Afr J TraditComplmentAltern Med 2016; 13 (5); 153-9.

Volume 15 No. 1 June 2020: 11-16
10. Ogunka-Nnoka C, Amadi B, Agomuo E, Amadi P. Ameliorative effects of some natural blood boosters on CP induced anemia in rats. J Appl life SciInt10(3): $1-11,2017$.

11. Anokwuru CP, Anyasor GN, Shokunbi OS, Sopekan $\mathrm{B}$, Osinuga OK, Afolabi OE, Arojojoye OB, Ezekiel $\mathrm{CN}$, Ramaite ID. Chemoprotective activity of aqueous leaf extract of Acalyphawilkesiana against cyclophosphamide-induced toxicity in rats. Asian Pac J Trop Med 2019;12:409-15

12. Fahey JW. Moringaoleifera: A review of the medical evidence for its nutritional, therapeutic, prophylactic properties. Part 1. Trees Life J 2005; 1(5):1-20.

13. Ghasi SE, Nwobodo, Ofili JO. Hypocholesterolemic effects of crude extract of leaf of Moringaoleifera Lam in high-fat diet fed wistar rats 2000; J Ethnopharmacol, 69(1): 21- 5 .

14. Kumar NA, Pari L. Antioxidant action of Moringaoleifera lams. (drumstick) against antitubercular drugs induced lipid peroxidation in rats. J Med Food 2002; 5(3): 171-7.

15. Bharali R, Tabassum J, Azad M.R. Chemomodulatory effect of M. oleifera Lam on hepatic carcinogen metabolizing enzymes, antioxidant parameters and skin papillomagenesis in mice. Asian Pac J Cancer Prev 2003; 4:131-9.

16. Rao CV, Ojha SK. Analgesic effect of MoringaoleiferaLam. leaf extract on rats, 2nd World Congress onBiotechnological Developments of Herbal Medicine.Luck now, India: NBRI; 2003.p. 42. MAPA $-02-911$.

17. Ray K; Hazra R and Guha D. Central inhibitory effect of Moringaoleifera root extract: possible role of neurotransmitters. Indian J of ExpBiol 2003; 41(11):1279-84.

18. Mahajan SG, Mali RG, Mehta AA. Effect of Moringaoleifera Lam. seed extract on toluene diisocyanate-induced Immune-mediated inflamma-tory responses in rats. J Immunotoxicol 2007;4(2):85-96.

19. Omeni AA, Alaiya TH, Nasiru EC, Adekanle E, OmozokpiaUM,Ofioghuma DO. The effects of Moringaoleifera lam leaf powder on the plasma glucose levels and some hematological indices of alloxan induced diabetic rabbits. Int J herbs Pharmacol Res 2015; 4 (1): 24-30.

20. Atta AH, Soufy H, Nasr SM, Soliman AM, Nassar SA, Maweri AA, Tamer H, Aziz AE, Hassan M, Desouky, 
Aboelfetoh M, Abdalla. Hepatoprotective and antioxidant effects of methanol extract of Moringaoleifera leaves in rats. Wulfenia J 2017; 24(3): 249-68.

21. Adegbite OA, Omolaso B, Seriki SA, Shatima C. Effects of Moringaoleifera leaves on hematological indices in humans. Ann of HematolOncol 2016; 3(8):1-7.

22. Sindhu S, Mangala S, Sherry B. Efficacy of Moringaoleifera in treating iron deficiency anemia in women of reproductive age group. Int J Phytother Res 2013; 3(4):15-20.

23. Nagashree R, Latha R, Karthikeyan V. Effect of leaves of Moringaoleifera on biochemical and physiological parameters in rats. J Nat Remedies 2011; 11(1):54-9.

24. Osman HM, Shayoub ME, Babiker EM. The effect of Moringaoleifera leaves on blood parameters and body weights of Albino rats and rabbits. Jordan J BiolSci 2012; 5(3): 147-50.

25. Otitoju O, Nwamarah JU, Otitoju GTO, Okorie AU, Stevens C, Baiyeri KP. Effect of Moringaoleifera aqueous leaf extract on some hematological indices in Wistar rats. Chem Process Eng Res 2014; 18; 26-30.

26. Islam KMN, Rahman ASMH, Al-Mahmud KA. Manual for care and use of laboratory animals. Animal resources branch. International Centre for Diarrhoeal Disease Research, Bangladesh; 2002.

27. Ali T, Javan M, Sonboli A, SemnanianS.Evaluation of the antinociceptive and anti-inflammatory effects of essential oil of Nepetapogonospermaj amzad et assadi in rats.DARU.2012;20:1-8.

28. Refinetti R, Horvath SM. Thermopreferendum of the rat: inter-and intra-subject variabilities. Behav Neural Biol 1989; 52 (1):87-94.

29. Rijn CM, Krijnen H, Menting-Hermeling S, Coenen AML. Decapitation in Rats: Latency to Unconsciousness and the 'Wave of Death'. PLoS One2011; 6(1): e16514.

30. Chukwuemeka I, Utuk GS, OkechukwuPCU,Ibiam UA, Aja PM, Offor CE. The effect of ethanol leaf extract of Jatrophacurcas on some hematological parameters of cyclophosphamide induced anemia in Wister rats. Eur J ApplSci 2015; 7(1):17-20.

31. Njan AA, Amali MO, Olatunji LO, Olorundare OE. An overview of the ethno-pharmacological potentials of Moringaoleifera Lam, 'The miracle tree'. Arch Bas App Med 2014; 2: 135-45.

32. Razis AFA, Ibrahim MD, Kntayya. Health benefits of Moringaoleifera. Asian Pac J Cancer Prev 2014; 15: 8571-6.

33. Okot-Asi TNE, Chinaka NO, Ofem OE, Josiah EI. Effect of Moringaoleifera Lam. ethanol leaf extract on hematology in phenyl hydrazine induced anemic albino Wistar rats. Am J PharmacolSci 2015; 3(3): 6773.

34. Moyo B, Masika PJ, Hugo A, Muchenje V. Nutritional characterization of Moringaoleifera (Moringaoleifera Lam.) leaves. Afr J Biotech 2011; 10 (60): 12925-33. 